\title{
Nitrogen balance after injuries
}

\section{By J. P. BulL, Medical Research Council Industrial Injuries and Burns Research Unit, Birmingham Accident Hospital, Birmingham I5}

An increased excretion of nitrogen after injuries in experimental animals and in man was described by Cuthbertson (1930). In a series of papers he and his colleagues discussed and explored almost all the facets of this phenomenon which have since been studied (see, e.g., Cuthbertson, I929, 1930, I936, I942; Cuthbertson \& Tompsett, I935; Cuthbertson, McGirr \& Robertson, 1939). He investigated the timing and extent of the nitrogen loss, its relation to different severities of injury, to immobilization, fever and nutrition, the associated changes of plasma proteins and of potassium, sulphur and phosphate metabolism, the source of nitrogen in the body, its partition in the urine and the possible role of breakdown products, hormones or nervous action in initiating and sustaining the response.

Such disturbances in recent clinical injuries are intrinsically more complex than those of standardized experimental trauma, and are more difficult to study in an adequately controlled way. There is no possibility of an initial stabilizing period, and the previous nutritional status cannot be known with precision. In the more severe injuries, therapy must necessarily be varied to meet individual requirements; nutrition is only one of these, and must be changed to permit other procedures. Nevertheless, some observations are possible in these cases, commonly on a 'natural history' rather than an experimental basis. Helpful parallels are also available from 'cold' operation cases, where the deliberate trauma of surgery is substituted for accidental injury. But the circumstances, nature and timing of injury and corrective procedures are sufficiently different to make one cautious in accepting operation as a very close analogy to accidental trauma.

\section{Complexity of nitrogen metabolism after injury}

The overall nitrogen balance is not entirely informative when one considers losses of whole protein, as in exudate or haemorrhage, and transfusions of similar materials on the same basis as oral feeding and urinary and faecal losses. Albright, Forbes \& Reifenstein (1946) have shown that plasma protein given intravenously is only slowly metabolized, and if nitrogen is so given in excess it will be excreted in the urine only after several days. Correspondingly, after transfusion of red cells excretion of excess nitrogen is even longer delayed (Levenson, Birkhill, Maloney \& Bell, 1949). Further, if there has been plasma loss, as from a burn, or blood loss from other injuries, intravenous replacement may be virtually direct, so that neither the loss nor the transfusion should appear in the nitrogen balance on the same basis as intake by mouth and urinary excretion. Any discussion of nitrogen balance in cases of injury must make this clear, but further consideration shows that the situation 
is even more complex. Even the quantities accepted for calculation are suspect; digestion and absorption of protein taken by mouth may well be disturbed in the severely injured patient, and renal excretion of nitrogen is frequently depressed. When one considers the details of the balance sheet within the body, the situation is clearly more complex again. We have, for instance, confirmed what was shown years ago in respect of altered proportions of plasma proteins. The total plasma protein is commonly somewhat low a few days after a severe burning injury, but electrophoresis shows much more extreme changes in the different fractions. The predominant early change is the progressive fall of the albumin fraction corresponding, in cases where we have also serial plasma-volume studies, to progressive reduction in total circulating albumin. An early change in the globulins is that the $\alpha_{2}$ fraction commonly rises in the first day or two and the rise is followed by a very great increase in the proportion and the total circulating quantity of $\gamma$-globulin. We have found $\gamma$-globulin in several patients at a higher level than albumin, even though the total plasma-protein concentration was within normal limits. This change must have profound implications for the oncotic pressure function of the plasma proteins, which is mainly related to albumin concentration, but for the present purpose we should note that, whatever the overall balance of nitrogen may be, the internal economy is grossly deranged. The example of plasma proteins is available since it can be easily investigated. Other protein systems may well show equivalent derangements when they can be more thoroughly studied. Let us consider some of the gross changes in body proteins in a patient with moderately severe burns. Such a patient will lose perhaps $\mathrm{I}-2 \mathrm{l}$. of exudate from the surface daily for the first I or 2 days; this quantity will contain about Io $g$ nitrogen/l. as plasma protein, the ratio albumin : globulin being slightly higher than that of the circulating plasma, though all protein fractions will be represented. If such a patient receives no transfusion, the circulating protein will be depleted and presumably the reserves of plasma protein will be called upon. If transfusion is given these losses can be replaced directly. In addition to external exudation, there will be protein in the extracellular fluid of the oedema surrounding the burned area. Masses of red cells will be marooned by the loss of fluid, will become sequestrated from the circulation and be ultimately broken down. As the cellular reaction to the burn develops there will be an accumulation of white cells which, as shown by Yuile, Lucas, Jones, Chapin \& Whipple (1953) have an intensely active nitrogen exchange. The damaged tissue itself will be lysed; some of the products will appear in the exudate and others in the circulation. Quite soon after injury there is evidence of new tissue formation, in particular epithelial remnants begin to proliferate and tend to form a new covering of the damaged area. In all these processes nitrogen exchange is involved. Since fluid loss from the circulation progressively decreases over the first day or two, it is not usual for transfusion to be continued beyond about $48 \mathrm{~h}$, but some loss of nitrogen in exudate continues. Many investigators have measured the quantities lost during these later phases after burning, and agree that they may be very large, though irregular from patient to patient, depending upon the depth of the burn as well as its surface area. The greatest losses are found in areas of full-thickness 
skin loss, and may amount to $8 \mathrm{~g}$ or more of nitrogen per day, even several weeks after injury. It is possible that these losses are a main cause of the depletion of serum albumin. What we know of blood loss in fracture cases suggests that it is an important cause of disturbance of plasma protein in these patients also. Adequate transfusion prevents at least part of the changes (Baar \& Topley, 1956).

So far we have not considered the raised excretion of nitrogen corresponding to what is described in postoperative patients and those with other injuries than burns. It is probably present in addition to the exudate losses, and its explanation and significance are still in doubt. Moore $\&$ Ball (1952) have shown how the changed metabolism after operation may be reproduced if the known effects of starvation (Benedict, I9I5), of immobilization (Deitrick, Whedon \& Shorr, I948) and ACTH in graded doses are combined in an experimental patient. There has been a great deal of experimentation and discussion on the role of adrenal cortical hormones in changing the nitrogen balance, and it is not possible to deal here with this very complex field.

It is generally agreed that the excreted nitrogen is mainly in the usual urea and ammonia fractions, though on occasion abnormal amounts of amino-acid or peptide appear in the urine (Nardi, I954; Eades, I955). It is suggested that the escape of amino-acids is due to a failure of tubular reabsorption, though studies of liver function after haemorrhage in rats show that synthesis of urea is disturbed, which may tend to cause amino-aciduria (Russell \& Long, 1946). Peptide excretion is unaffected by extra protein feeding, appears to be unrelated to antidiuretic activity, and the quantity of urinary peptide appears to give some indication of the patient's prognosis (Balikov, I954; Baar, 1956). Creatinine excretion is somewhat raised, though not in proportion to the amount of damage to muscle (Frawley, Artz \& Howard, r 955); but in general a normal excretory pattern is found, with an increase in quantity of all nitrogenous materials. The source of this nitrogen in the body is probably mixed, which in view of the increasing knowledge of the turnover of nitrogenous products in the metabolic pool, is not surprising. As Cuthbertson (1929) and Cuthbertson et al. (1939) showed, it is unlikely that all the nitrogen can come from the injured area, and there appears to be a general increase of katabolism, possibly combined with a diminished anabolism of protein in which ACTH and adrenal cortical hormones may well be playing a part. It has been shown in experimental injuries (Munro \& Cuthbertson, I943) and in patients (Browne, I945) that prior depletion of protein prevents the increased nitrogen excretion after injury. It thus seems likely that the more labile protein stores are first used, and when these are exhausted further tissue protein is not raided. Studies of separate amino-acids have not yielded clear evidence of specific excesses or deficiencies, though shortage of methionine has frequently been suspected. Part at least of the raised excretion of nitrogen may be due to wastage of those amino-acids of katabolized proteins that are not required as building blocks (Co Tui, 1953). If this were the only explanation of the raised excretion, it might be expected, as Peters (1948) has pointed out, that the excretion would be at least as marked in debilitated as in normal patients, and that there would be a better response to feeding with protein supplements. 
Contrary to what is sometimes stated, it has been found that the severely burned patient has a raised metabolic rate. Cope, Nardi, Quijano, Rovit, Stanbury \& Wight (1953) made serial observations upon fifteen patients with burns and found in many a metabolic rate raised by $30-60 \%$, i.e. to levels equivalent to those in moderate or severe thyrotoxicosis. They consider that the raised rate could fully account for the wasting seen after severe burns, but could not be attributed to increased activity of the thyroid. The raised metabolic rate implies a need for calories over and above that for normal maximal nitrogen sparing. Consistent with this is the finding of Werner, Habif, Randall \& Lockwood (r949) that with generous calorie input the negative nitrogen balance after moderately severe operations could be prevented.

\section{Is a negative balance obligatory}

It has been keenly disputed whether the raised nitrogen excretion after injury can be matched by a raised input so that equilibrium is obtained. Some of Cuthbertson's ( $193^{6}$ ) fracture cases received large quantities of protein, which resulted in increased excretion, and balance or retention was never attained. Similar results have since been frequently reported, though many of the published cases supposedly showing an inevitable negative balance demonstrate that adequate nitrogen input was never achieved. Other studies (e.g. Mulholland, Co Tui, Wright \& Vinci, r943; Werner, r945) have suggested that the negative balance at least in moderate injuries and after moderately severe operations can be offset by raised input. It remains something of a mystery why in certain cases this cannot be achieved. For instance, after fractures and spondylolisthesis obligatory negative balances are reported, yet not after the operation of osteotomy. Patients after certain gall-bladder operations and repairs of ventral hernias, but not appendicectomies, are reported to be maintained readily in equilibrium, yet gastrectomy cases are sometimes reported as in negative balance and sometimes in equilibrium. The limiting factor is not the quantity of input, since by means of intravenous or tube feeding enormous quantities of nitrogen can be given if so desired. It is possible that the quality of the protein or its specific proportions of separate amino-acids are important, but Cuthbertson ( 1936 ), for instance, tried several different mixtures including supplementation with cystine and obtained almost identical results as with gelatin supplements.

In our own studies on burns, we have made some incidental observations on nitrogen balance in experiments mainly directed to electrolyte exchange. If we take nitrogen input and compare it with renal nitrogen output in patients who have been, in our view, adequately treated by transfusion, we find little difficulty in obtaining 'apparent positive' nitrogen balances. Though this clearly does not represent the whole story, it should be remembered that comparison of intake with renal output is the main ground for claims that the 'katabolic phase' makes negative balances obligatory. From this point of view exudate losses should not necessarily be included, since they do not represent katabolism but rather loss of part of an organ equivalent perhaps to an amputation or plasmapheresis. 
When it comes to injuries other than burns, my colleagues Flear $\&$ Clarke (I955) have studied a series of patients with moderately severe fractures who received transfusion replacement of blood loss of varying adequacy. Raised nitrogen excretions were found particularly at 5-ro days after injury and, though the differences between transfused and non-transfused cases were not spectacular, a positive correlation between adequacy of transfusion and nitrogen balance was found, suggesting that correction of circulatory volume in these cases favoured a less extreme response to the injury. No special dietary treatment was used, and in the self-selected hospital diet the nitrogen content was never sufficient to be expected to produce equilibrium or positive balances. Cuthbertson's (1936) patients receiving about the same amount of nitrogen as those in our series, also showed approximately the same negative balances as our untransfused patients.

\section{Therapeutic implications}

It has been questioned whether one should strive in therapy to obtain nitrogen equilibrium after injury. There is no conclusive evidence that the patient is much the worse for a period of negative balance or much the better for maintaining a positive balance; but this is not to say that we should be so lost in admiration of the so-called 'natural' responses to trauma as to omit rational therapy. Studies of the clinical effects of, for instance, correction of blood volume by transfusion, show that the sequence of electrolyte changes, the anaemia and other features of the illness of trauma are by no means inevitable (Topley \& Fisher, 1956). That nitrogen balance is less spectacularly altered means at least that the syndrome is not unitary. Patients with moderate injuries need have only minimal biochemical and nutritional disturbances, and one hopes that increasing numbers of more severe injuries can have their 'severity' modified by early and efficient treatment.

In the present state of knowledge, the following principles seem rational:

(I) Where there are known losses of blood proteins, these should be replaced by transfusion. Plasma and blood are the rational replacement fluids for burns, and blood transfusion for other injuries. Recent studies show that these losses are greater than has previously been assumed, and we are probably only now beginning to obtain adequate correction.

(2) Generous supplies of protein and calories should be available for the injured patient in his diet. Many ordinary hospital diets are inadequate in this respect.

(3) There is no practical limit to the amount of nitrogen that can be given, either intravenously as hydrolysate or amino-acid mixtures or orally as high-protein tube feeds. It is rational to minimize the nitrogen loss and to anticipate the subsequent strongly anabolic phase of healing by supplements to ordinary feeding. Inputs of the order of $0.5^{-1} \mathrm{~g}$ nitrogen $/ \mathrm{kg} /$ day and $40-60 \mathrm{Cal} / \mathrm{kg}$ can be given to the more severely injured patients.

(4) We must not forget that in the severely injured patient a multitude of complex processes is at work, and that it is presumptuous to expect them to be explained under any single, simple theory. 


\section{REFERENCES}

Albright, F., Forbes, A. P. \& Reifenstein, E. C. (1946). Trans. Ass. Amer. Phycns, 59, 221.

Baar, S. (1956). 7. clin. Path. 9, I44.

Baar, S. \& Topley, E. (1956). Acta med. scand. 153, 3 г9.

Balikov, B. (1954). Surgical Research Unit, Brooke Army Medical Center, Annual Report, 954.

Bartter, F. C., Fourman, P., Forbes, A. P., Jeffries, W. M. \& Albright, F. (1949). Metabolic Interrelations. Transactions of the First Conference, p. 137. New York: Josiah Macy Jr. Foundation.

Benedict, F. G. (1915). Publ. Carneg. Instn, no. 203.

Browne, J. S. L. (1945). Conference on Metabolic Aspects of Convalescence. Transactions of the Ninth Meeting, p. 15. New York: Josiah Macy Jr. Foundation.

Co Tui (I953). F. clin. Nutr. I, 232.

Cope, O., Nardi, G. L., Quijano, M., Rovit. R. L., Stanbury, J. B. \& Wight, A. (I953). Ann. Surg. 137,165 .

Cuthbertson, D. P. (1929). Biochem. F. 23, 1328.

Cuthbertson, D. P. (1930). Biochem. F. 24, 1244.

Cuthbertson, D. P. (1936). Brit. F. Surg. 23, $5 \circ 5$.

Cuthbertson, D. P. (1942). Lancet, 242, 433.

Cuthbertson, D. P., McGirr, J. L. \& Robertson, J. S. M. (1939). Quart. F. exp. Physiol. 29, 3.

Cuthbertson, D. P. \& Tompsett, S. L. (1935). Brit. F. exp. Path. 16, 47 I.

Deitrick, J. E., Whedon, G. D. \& Shorr, E. (r948). Amer. Y. Med. 4, 3.

Eades, C. H. (1955). F. clin. Invest. 34, $175^{6}$.

Flear, C. T. G. \& Clarke, R. (1955). Clin. Sci. r4, 575.

Frawley, J. P., Artz, C. P. \& Howard, J. M. (1955). Battle Casualties in Korea. U.S. Army Medical Services, I, zo9.

Levenson, S. M., Birkhill, F. R., Maloney, M. A. \& Bell, J. A. (1949). Ann. Surg. 130, 723.

Moore, F. D. \& Ball, M. R. (x952). The Metabolic Response to Surgery. Springfield, Ill.: C. C. Thomas.

Mulholland, J. H., Co Tui, Wright, A. M. \& Vinci, V. J. (1943). Ann. Surg. 117, 5 12.

Munro, H. N. \& Cuthbertson, D. P. (1943). Biochem. F. 37, xii.

Nardi, G. L. (1954). F. clin. Invest. 33, 847 .

Peters, J. P. (1948). Amer. F. Med. 5, roo.

Russell, J. A. \& Long, C. N. H. (1946). Amer. F. Physiol. 147, 175.

Topley, E. \& Fisher, M. R. (1956). Brit. F. clin. Practice, 10, 770.

Werner, S. C. (1945). Conference on Metabolic Aspects of Convalescence. Transactions of the Ninth Meeting, p. 54. New York: Josiah Macy Jr. Foundation.

Werner, S. C., Habif, D. V., Randall, H. T. \& Lockwood, J. S. (1949). Ann. Surg. 130, 688.

Yuile, C. L., Lucas, F. V., Jones, C. K., Chapin, S. J. \& Whipple, G. H. (1953). F. exp. Med. $98,173$. 